\title{
Volga Sabaleuskaya
}

Belarusian Institute of Law. Grodno Branch, (Belarus)

ORCID: https://orcid.org/0000-0002-8668-7899

\section{The Participation of Jews in the Tobacco Production of the Grodno Province (Second Half of the $19^{\text {th }}$ to the Early $20^{\text {th }}$ Centuries)}

Udział Żydów w produkcji tytoniu w guberni grodzieńskiej (druga połowa XIX - początek XX wieku) удзел габрэяў у вытворчасиі тытунюу Гродзенскай губерні (другая палова XIX - пачатак XX стагоддзя)

\begin{abstract}
In the second half of the $19^{\text {th }}$ to the early $20^{\text {th }}$ centuries there was a rapid development of industry and trade on the territory of Belarus. Jews had made a significant contribution to the process. At that time they made up at least 50 percent of the population of cities and towns. Despite the popularity of economic history there have been no attempts to comprehend the development of the tobacco industry as a separate type of production and to identify the place of Jewish entrepreneurs in this process. This led to the relevance of this study, the objectives of which is to characterise the legal framework for the development of the tobacco industry and the analysis of the dynamics of the Jewish tobacco enterprises of Grodno (Grodno Guberniia).

Historical, logical and classification research methods are based on chronological and event-based approaches to the studied facts, and on the principle of historicism, which makes it possible to consider historical phenomena in the context of the era. The result of the research is the identification and understanding of a wide range of archival sources on the history of the industry of Belarus from the second half of the $19^{\text {th }}$ to the early $20^{\text {th }}$ centuries.

The legal basis for the development of tobacco production consisted of excise statutes of 1838-1901, which contributed to the process of monopolization and the emergence of numerous illegal small artisanal workshops. Jews formed the majority in the legal and illegal production of tobacco products on the territory of Grodno (Grodno Guberniia). During the second half of the $19^{\text {th }}$ in the early $20^{\text {th }}$ centuries there was progress in tobacco production. Penetration of science into production, establishment of new technologies, modernization of production were carried out. Large enterprises demonstrated the greatest stability due to technological and organizational advantages. Tobacco products of Grodno (Grodno Guberniia) were competitive in cost and quality, and commercial advertising technologies were used in their implementation. They held a stable and strong position in the market of the Russian Empire.
\end{abstract}

Keywords: tobacco products, production, Jews, Grodno 


\begin{abstract}
Abstrakt
W II poł. XIX i na pocz. XX w. na terenie Białorusi miał miejsce szybki rozwój przemysłu i handlu, do którego w znacznej mierze przyczynili się Żydzi, stanowiący nie mniej niż 50\% ludności miast i miasteczek. Mimo zainteresowania naukowców historią ekonomiczną dotąd nie podjęto próby opisu kwestii rozwoju na Białorusi przemysłu tytoniowego jako odrębnej gałęzi przemysłu oraz ustalenia roli, jaką odegrali w tym procesie żydowscy rzemieślnicy. Brak badań odnoszących się do wskazanych kwestii zadecydował o podjęciu niniejszej analizy, której celem było dokonanie charakterystyki bazy aktów prawnych dotyczących działalności tytoniowej, a także analiza dynamiki rozwoju należących do Żydów zakładów tytoniowych w Grodnie i guberni grodzieńskiej. Zastosowano zróżnicowane metody badania: metodę historyczną, metodę opisu i klasyfikacji, odwołujące się do chronologicznego opisu faktów oraz zasad historyzmu, które pozwoliły na analizę zjawisk historycznych w kontekście epoki. Rezultatem badania jest opis licznych źródeł archiwalnych z zakresu historii przemysłu na Białorusi w II poł. XIX i na pocz. $\mathrm{XX}$ w. Ustalono, że podstawę prawną dla rozwoju przemysłu tytoniowego stanowiły zarządzenia w sprawie stawek podatku akcyzowego z lat 1838-1901, które sprzyjały procesom monopolizacji oraz powstawaniu licznych, nielegalnych zakładów chałupniczych. W guberni grodzieńskiej Żydzi przeważali zarówno w legalnej, jak i nielegalnej strefie produkcji tytoniu. W II poł. XIX oraz na pocz. XX w. przemysł tytoniowy znacznie się rozwinął: wprowadzano w życie osiągnięcia naukowe, wykorzystywano nowe technologie, dokonano modernizacji produkcji. Dzięki przewadze technologicznej i organizacyjnej najsilniejszą pozycję posiadały duże przedsiębiorstwa. Ze względu na wysoką jakość i przystępną cenę wyroby tytoniowe pochodzące z guberni grodzieńskiej mogły konkurować z innymi. Wyroby te miały mocną pozycję na rynku rosyjskim.
\end{abstract}

Slowa kluczowe: wyroby tytoniowe, produkcja, Żydzi, Grodno

\title{
Анатацыя
}

У другой палове XIX - пачатку XX ст. на тэрыторыі Беларусі назіраўся хуткі рост прамысловасці і гандлю. Істотны ўнёсак у гэты працэс зрабілі габрэі, якія складалі не менш за 50\% насельніцтва гарадоў і мястэчак. Нягледзячы на папулярнасць эканамічный гісторыі адсутнічаюць спробы асэнсаваць развіццё тытунёвай прамысловасці як асобнай галіны вытворчасці і выявіць месца ў гэтым працэсе габрэйскіх прадпрымальнікаў. Гэта абумовіла актуальнаць дадзенага даследавання, задачамі якога з'яўляецца характарыстыка прававой базы для развіцця тытунёвай вытворчасці і аналіз дынамікі развіцця яўрэйскіх тытунёвых прадпрыемствау Гродзенскай губерні. Метады даследавання: гістарычны, лагічны і класіфікацыйны, заснаваны на храналагічным падыходзе да фактаў, што дае магчымаць разгледзець гістарычныя з'явы ў кантэксце эпохі. Вынікам даследавання з'яўляецца выяўленне і асэнсаванне шырокага кола архіўных крыніц па гісторыі прамысловасці Беларусі другой паловы XIX - пачатку XX ст. Прававую базу для развіцця тытунёвай вытворчасці складалі акцызныя ўставы 1838-1901 гг., якія спрыялі працэсу манапалізацыі і з'яўленню шматлікіх нелегальных дробных саматужных майстэрняў. Габрэі пераважалі ў сферы легальнай і нелегальнай вытворчасці тытунёвых вырабаў у Гродзенскай губерні. На працягу другой паловы XIX - пачатку XX ст. назіраўся прагрэс у сферы вырабу тытуню. Ажыццяўлялася пранікненне навукі ў вытворчасць, укараненне новых тэхналогій, мадэрнізацыя вытворчасці. Найбольшую ўстойлівасць за кошт 
тэхналагічнай і арганізацыйнай перавагі дэманстравалі буйныя прадпрыемствы. Вырабы тытуннікаў Гродзенскай губерні былі канкурэнтаздольныя па кошце і якасці, пры іх рэалізацыі выкарыстоўваліся тэхналогіі камерцыйнай рэкламы. Яны займалі ўпэўненыя пазіцыі на рынку Расійскай імперыі.

Ключавыя словы: тытунёвыя вырабы, вытворчасць, яўрэі, Гродна

$\mathrm{T}$

The factory and the railway road are the symbols of the $19^{\text {th }}$ century, filled with the spirit of progress. In the second half of the $19^{\text {th }}$ century, the industrial development transformed and influenced the way of life of the population, contributed to the formation of new social groups, changed the appearance of urban settlements, and gave impetus to the development of education. An important role in this process was played by the representatives of the Jewish community, who made up at least $50 \%$ of the population in the majority of cities and towns of the Belarusian part of the Jewish settlement line.

The problem of industrial development in the post-reform Belarus received much attention in the Soviet historiography, including the works of Z. Abezgauz (1971), V. Saladkov (1957) and M. Bolbas (1977). In the historical science of the turn of the $20^{\text {th }}$ and $21^{\text {st }}$ centuries, the economic development of cities attracted the attention of Z. Šybeka (1997), A. Kištymaǔ (2002), Bašmakoǔ (2008) and the economic history of Belarus acquired the status of an academic discipline (Golubovič, 2001). At the same time, there have been no attempts to comprehend the development of the tobacco industry in Belarus from the second half of the $19^{\text {th }}$ to the early $20^{\text {th }}$ centuries as a special field of production or to identify the role of the representatives of the Jewish communities in this process, which led to the choice of the topic of this article.

Until the middle of the 1830 s, there was the state monopoly on the production of tobacco products in the Russian Empire. In 1838, the Excise Statute was introduced, according to which tobacco products had to be sealed with parcels, i.e. special strips of paper issued by the Excise Department to be put on packets of tobacco or cigarettes. The cost of the parcel amounted to $20 \%$ of the price of tobacco products. It was necessary to obtain a certificate for the production of tobacco products, whereas factories could be founded exclusively in cities. This measure led to the concentration of tobacco factories in the Grodno province, in the provincial centre and district towns. After 10 years, the rules concerning the production and sale of tobacco products changed:

The Statute of 1848 stipulated an increase in the excise tax to $25 \%$. Homemade production of tobacco was prohibited and a mandatory sample of parcels of at least 500 roubles per year was established for manufacturers (Akciz, 1893, p. 330).

The Statute on Tobacco Excise of 1861 increased the tax on this type of activity, which led to a decrease in the proportion of small artisanal production and the devel- 
opment of illegal production of tobacco products. This includes the Grodno province, which will be discussed below. For the production of tobacco products, it was still necessary to acquire trade certificates and parcels, while the minimum amount for which the manufacturer was obliged to buy the parcels on the territory of the Grodno province and present-day Belarus reached the amount of 1500 roubles (Polnoe, 1863, No. 37196).

According to the Excise Statute of 1871, the excise tax was at 30-33\% of the sale price. In the capitals, Riga and Odessa, the minimum amount for which it was necessary to purchase parcels increased to 10,000 roubles. In other cities, including Grodno, it was up to 6,000. It was possible to pay this fee in secured instalments (Polnoe, 1874, No. 49702).

The rules changed on 1 January 1878, when the fixed price of tobacco products was abolished. A total average price of packages for tobacco, cigarettes, cigars and cigarettes was established, while reduced cost packages were introduced for makhorka (Akciz, 1893, p. 330), which led to the activation of the tobacco business in the Grodno province.

The Tobacco Statute of 1882 allowed for the production of tobacco products only in the factories which had obtained certificates and parcels. Only manufacturers and owners of wholesale tobacco warehouses were allowed to purchase tobacco, whereas only the owners of tobacco plantations were allowed to manufacture tobacco products for personal use at home, and even so with the use of ordinary knives rather than special tools. It was forbidden to involve workers in this process (Polnoe, 1886, No. 895). With the introduction of this measure, the number of criminal cases of illegal production of tobacco products in the Grodno province increased significantly.

On 1 January 1893, an additional excise duty for tobacco enterprises was introduced. It amounted to 2 roubles per pood or 5 kopecks per pound of tobacco products produced (NHAB, f. 26, inv. 1, d. 283, pp. 16, 25).

On the basis of the Statute on Excise Duties of 1901, the so-called surplus tax at $10 \%$ of the patent price in favour of the State Treasury and $10 \%$ in the provincial zemsky fee was levied on issuing patents for tobacco and makhorka factories and wholesale warehouses (NHAB, f. 24, inv. 4, d. 4, p. 2). The introduction of additional fees had a negative impact on the development of tobacco production in the Grodno province and led many small workshops to move towards the informal economy. This, in turn, gave rise to the reduction of excise duties in 1890-1910.

Despite the fact that the geographical conditions of the Grodno province, i.e. its climate and soil, were suitable for tobacco cultivation, this branch of agriculture did not undergo significant development. Tobacco was grown mainly for farmers' own needs, and they supplied it to small factories in small quantities. According to the data of 1909 , tobacco from local plantations at the Grodno province factories amounted to mere $0.005 \%$ of the processed raw materials (NHAB, f. 23 , inv. 1 , d. 145, p. 170). As it was noted in the report of the Grodno Control Chamber, 
the number of local plantations in the last decade, from 1898 to 1907 , continued to decrease with every year. Small plots of land were allocated under plantations [...], and the amount of the tobacco harvested did not reach even 300 poods. The quality of the tobacco cultivated in the province is the lowest, which is why prices do not exceed 3 roubles 50 kopecks per pood (NHAB, f. 23, inv. 1, d. 145, p. 167).

Table 1. Development of Tobacco Production in the Grodno Province in 1898-1907

\begin{tabular}{|c|c|c|c|c|}
\hline Year & $\begin{array}{c}\text { Number of settlements of } \\
\text { the Grodno province where } \\
\text { tobacco was grown }\end{array}$ & $\begin{array}{c}\text { Number of } \\
\text { plantations }\end{array}$ & $\begin{array}{c}\text { Amount of land under } \\
\text { tobacco crops, in } \\
\text { dessiatins }\end{array}$ & $\begin{array}{c}\text { Collected poods } \\
\text { of tobacco }\end{array}$ \\
\hline 1898 & 208 & 3604 & 9,5 & 471 \\
\hline 1907 & 12 & 423 & 2 & 278 \\
\hline
\end{tabular}

NHAB, f. 23, inv. 1, d. 145, p. 167.

As presented in Table 1, over the ten years from 1898 to 1907, the area planted with tobacco crops in the Grodno province decreased 4.75 times, while production volumes decreased 1.7 times. Upon the analysis of the situation, a Control Chamber official came to the conclusion that the tobacco production in the province at the turn of the $19^{\text {th }}$ and $20^{\text {th }}$ centuries was in its infancy and unlikely to ever develop in future.

Imported tobacco amounted only to $0.8 \%$ of processed raw materials in the tobacco factories of the Grodno province. Makhorka, leaf and cigar tobacco, bagun and roots were the primary supplies imported from various provinces of the Russian Empire (NHAB, f. 23, inv. 1, d. 145, p. 170). For example, tobacco was brought to the Neman Tobacco Factory from the wholesale warehouse of the Popov brothers in Riga, the Kalvari makhorka factory of Trotsky and Sashman, the tobacco factories of A. Berman in Volkovysk, Weinstein and R. Aranovskaya in Kovno, the wholesale warehouses of L. Y. Zhernovsky and I. Pinchuk in Gorodok, D. Shevchenko and I. Ioffe in Moscow in the village of Olishevka of the Chernigov province (NHAB, f. 30, inv. 1, d. 500, pp. 7-8, 21-22, 24-25, 26-27, 105).

Since the 1860 s, the leading position in the production of tobacco not only in the Grodno province, but also in the whole of Belarus was occupied by the enterprise of the Jewish Shereshevsky family in Grodno. In the 1880s, it acquired parcels totalling about half a million roubles a year (NHAB, f. 1, inv. 8, d. 2429, p. 2). In the 10 years of the $20^{\text {th }}$ century, $36 \%$ of annual tobacco processing took place there, while $84 \%$ of the excise tax in the province was received by the Treasury. As evidenced in the report of the Grodno Control Chamber for 1909, the productivity and income brought to the Treasury by the province occupied one of the first places in the entire Russian territory (NHAB, f. 23, inv. 1, d. 145, p. 169).

The permission was given by the provincial board on 17 October 1861 (NHAB, f. 1 , inv. 22, d. 1089, p. 1), but the enterprise was opened in 1862. The Jews Leiba Shereshevsky and Abram Gordon founded the factory, the latter was soon replaced by Iosel, Leiba Shereshevsky's son. In 1873, Iosel Leibovich Shereshevsky assumed 
full responsibility for the management of the fast-growing business. After the reconstruction of the factory and the transfer of production to a specially rebuilt building on Mostovaya street in 1880, he was partnered by a merchant named Fayvel Russota (S dymkom, 2018). The enterprise expanded over 8 years, with the third floor of the Mostovaya street building now completed (NHAB, f. 8, inv. 2, d. 596, pp. 2-5). The production needs were served by the tobacco sleeve factory founded in 1884, headed by the son of Iosel Shereshevsky, Isaac. In 1896, it produced cigarette sleeves for 10,810 roubles per year (Perečen', 1897, pp. 200-201).

On 31 December 1906, in order to counter the monopolisation of the tobacco industry, which increased in the early $20^{\text {th }}$ century not only in Russia but also on a global scale, the tobacco factory was transformed into a joint-stock company under the brand name Shereshevsky's Joint Stock Company of Grodno Tobacco Factory 'Neman', with the Jews I. L. Shereshevsky, F. Sh. Russota, G. V. Geller and G. H. Livshin as board directors. The shares were distributed among the members of the Shereshevsky and Russota family: the shareholders were S. I. and G. I. Shereshevsky, S. F. and G. F. Russota (NHAB, f. 30, inv. 1, d. 249, p. 61). This is characteristic of the early formation of capitalism. As Eric Hobsbaum noted, 'Patriarchal family autocracy prevailed in the sphere of governance' (Hobsbaum, 1999, p. 302).

During the 1860s - 1920s, Shereshevsky's factory was the leader in the tobacco production of Belarus in terms of the level of technological development. It was equipped with the state-of-the-art apparatus such as mechanical machines for the manufacture of cigarettes and cartridges as well as steam and electric motors. The enterprise exhibited distinct geography of tobacco products supply. In the early $20^{\text {th }}$ century, they were delivered to the provinces of Grodno, Vilnius, Vitebsk, Volyn, Kaunas, Courland, Livonia, Minsk, Mogilev, Moscow, St. Petersburg, Kherson, Kharkov, Chernigov, Chernomorsk, and Privislyansk (NHAB, f. 23, inv. 1, d. 145, p. 170). The assortment was varied - in 1896, Shereshevsky's factory produced smoking tobacco and snuff, makhorka, cigarettes, and cigars at 815220 roubles per annum (Perečen', 1897, pp. 666-667).

The largest company in the Grodno province, it employed 1,186 people in 1914. Among the employees were a manager named Geller, a cashier named Paykin as well as 18 clerks. Every warehouse had a manager and six workers. The technical staff consisted of twelve people (machinists, masters and assistant machinists). The workshops employed 1,147 workers, 798 (70\%) of whom were women. It should be added that the factory bought in 1912 by the board of Shereshevsky's Joint Stock Company of Grodno Tobacco Factory 'Neman' employed a manager, a clerk, two machinists, a master and 84 Jewish adult workers (NHAB, f. 30, inv. 1, d. 620, pp. 1, 5). The products of the Shereshevsky's factory were of high quality and received medals at numerous exhibitions (NHAB, f. 1, inv. 8, d. 2429, pp. 4-22).

Shereshevsky's factory was an innovator not only in the field of advanced production technologies. At the turn of the $19^{\text {th }}$ and $20^{\text {th }}$ centuries, its specialists developed solutions for marketing problems with the help of commercial advertising. Attempts were made to decorate cigarette cases with elegant gold stripes. This innovation could 
not be implemented as the law stipulated there should be no 'images of any kind' applied on tobacco factory products (NHAB, f. 30, inv. 1, d. 475, p. 13).

In order to increase consumer demand for its tobacco products in the Kingdom of Poland, the management of Shereshevsky's Joint Stock Company of Grodno Tobacco Factory 'Neman' sought permission to print labels in Polish. Since the revolts of 1830-1831 and 1863-1864, it was more a political than an economic issue. The Polish language was banned as a means of promoting national culture on the territory of present-day Belarus. It was necessary to obtain the permission of the provincial authorities to print labels with inscriptions not only in Russian but also in Polish. In 1884, this permission was requested by the administration of the tobacco factory of a Jewish businessman named M. H. Silberblatt, who worked in Bialystok as Isaac Zabludovsky (NHAB, f. 1, inv. 8, d. 1263, p. 1). In the same year, similar petitions were filed by Bialystok Jews: Yudel Novogrudsky, whose tobacco factory operated as F. Eisenstatt, and I. A. Gorfinkel (NHAB, f. 1, inv. 8, V. 1266, D. 1; V. 1264, D. 1, 21). All these manufacturers undertook to supply tobacco products, labelled in Russian and Polish, only in the Kingdom of Poland.

According to a circular of 3 December 1889, labels in Polish with the permission of the provincial police can be supplied only the products entering the trade network of the Kingdom of Poland (NHAB, f. 1, inv. 8, d. 2429, p. 1). On behalf of the Vilno Governor-General, the police warned all tobacco traders in the Grodno province that

any tobacco products with such labels or with any type of Polish inscriptions be found on their premises, such products will be confiscated, and those who sell them will be fined (NHAB, f. 1, inv. 8, d. 2361, p. 1).

Applying for permission to print labels in Polish, I. L. Shereshevsky claimed that his products, manufactured just on the border with the Privislyansk region, were sold primarily in Poland. He requested an accelerated decision, because

\footnotetext{
a long-term absence of my products under these labels from the market of the Kingdom of Poland will, as a result, lead to their disappearance therefrom, and, besides the loss incurred by the treasury and my business, it will reduce the earnings of the 1,300 people working at my factory (NHAB, f. 1, inv. 8, d. 2429, p. 2).
}

The labels of tobacco products had a special design. Different printing techniques were used to attract buyers: polychrome printing, vignettes, wreaths, ornaments, decorative fonts (italic, bold). The label of cigarettes named 'Bogactwo', for instance, was decorated with red, white and black inscriptions on a gold background, the title was italicised and in decorative font, with a number of complex decorative vignettes (NHAB, f. 1, inv. 8, d. 2429, p. 4). On the labels various drawings were applied, for ex-

\footnotetext{
'Wealth'.
} 
ample, the 'Rolnicze'2 cigarettes were decorated with pastel-painted idyllic landscape with a ploughman, a team of oxen, and a stork hovering above. A modest brown package of 'Tramvaj' ${ }^{3}$ cigarettes had an image of a tram-horse with passengers. (NHAB, f. 1 , inv. 8 , d. 1262 , p. 21).

The creators of advertising products of the Shereshevsky's factory appealed to the patriotic feelings of the inhabitants of the Kingdom of Poland. The labels of the 'Warsaw' cigarettes were dominated by soft pastel colours and gold, including a recognisable landscape of the Lazienki Park in Warsaw, associated with the last king of Republic of Poland and the lost independence of the Polish state. Labels of the 'Pije Kuba do Jakuba'4 cigarettes depicted two nobles in traditional Sarmatian costumes, holding glasses of red wine, presented against the background of a manor house surrounded by a garden, which was to evoke nostalgic memories of the 'golden age' of the Republic of Poland. On the one side of the "Nasza chwała' ${ }^{5}$ cigarettes package, there is a portrait of a lady, while the other side shows notes and an inscription reading 'Zacnej primadonnie polskiej. Marsz Lewandowskiego'6. They presented a series of tobacco products under the heading 'Polish Artists' (NHAB, f. 1, inv. 8, d. 1262, pp. 1-28).

The names of the Shereshevsky tobacco products had even an advertising subtext. 'Pije Kuba do Jakuba' rhymed and was easy-to-remember, while the 'Pal Pan!' brand expressed a vigorous call to action. Such brands as the 'Pleasant' cigarettes, 'Lithuanian Select' makhorka, or the 'Strong' tobacco hinted at the high quality of the goods (NHAB, f. 1 , inv. 8, d. 1262, p. 10, 11; d. 2429, pp. 8, 10, 22). Romance travels were an inspiration for such brands as 'Kentucky', 'Florida', 'Bafra', 'Amur', 'Varna', or 'Saint Petersburg', while 'Voitovsky's', 'Civil', 'Chairman's', 'Luxury', 'Wealth', 'Honor', 'Lord's' reminded of social prestige (NHAB, f. 1, inv. 8, d. 1262, pp. 1-28; d. 2429 , pp. $4,5,18,20$ ). The production of the 'Kalendarz's cigarettes proved to be an excellent marketing move. The label differed between particular varieties, together representing the entire calendar for 1885 along with holidays. Images of medals awarded to Shereshevsky's cigarettes and tobacco at various exhibitions were intended to reinforce the buyers' confidence in the product quality. The inscription 'est. 1862' indicated time-tested quality, whereas the image of the factory brand warned against counterfeits (NHAB, f. 1, inv. 8, d. 1262, pp. 1-28; d. 2429, pp. 17, 18, 20).

The factory of I. L. Shereshevsky was not the only tobacco factory owned by the representatives of the Jewish community in the Grodno province. In 1862, Shepshel Robinson and Benjamin Gorfinkel were allowed to establish a factory in Bialystok (NHAB, f. 1, inv. 22, d. 1267, p. 1). In 1870, the factories of smoking tobacco and

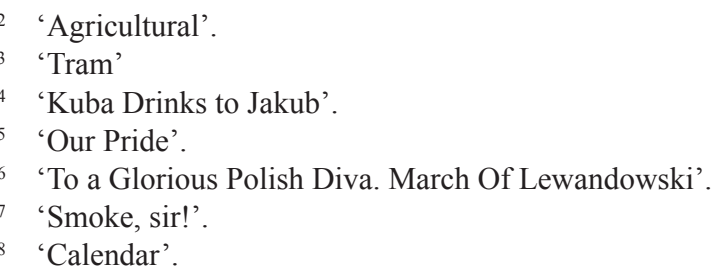


cigarettes operating in that city belonged to merchants named I. Bain (on 3986 roubles a year) and G. Neymark (on 4047 roubles a year) (NHAB, f. 1, inv. 22, d. 1861, p. 2728). In the mid-1880s, a tobacco factory of Wolf Friedman operated in Ciechanowiec. Its products were sold in the Kingdom of Poland (NHAB, f. 1, inv. 8, d. 1159, pp. 1, 4).

The mid-1880s saw a decline in the industry development connected with the economic crisis. In January 1884, large factories began to work part-time and reduced the number of employees, while many small businesses went bankrupt. In Bialystok, Abraham Nemtsevich had to halt production at his the tobacco factory, where 30 people worked until the middle of 1884. Of 30 workers who worked at the factory of Feivel Eisenstatt before the crisis, only 10 retained their jobs. At the tobacco factory of Isaac Zabludovsky, 40 of 134 workers were dismissed, whereas 5 people out of 95 were dismissed from the Gorfinkel's factory. All these enterprises belonged to Jewish manufacturers and employed Jewish workers (NHAB, f. 1, inv. 8, d. 1155, pp. 18, 23, 25).

Among the makhorka factories owned by Jewish proprietors in the early $20^{\text {th }}$ century, there were factories of F. Yanovsky and A. Darman in Bialystok, the factory of Pomerants in Pruzhany, and the factory of Hinkie Muginstein and Gdalia Gechtkopf in Brest (NHAB, f. 1, inv. 9, d. 1429, pp. 297-298; 24, inv. 4, d. 4, pp. 22, 23). In 1907 , three tobacco industry enterprises in the province produced both makhorka and tobacco, while four focused only on the production of makhorka (NHAB, f. 23, inv. 1, d. 145, p. 168). In 1908, the former employees of the I. L. Shereshevsky's factory who had lost their jobs due to the mechanisation of production opened a 'Manual Labor' factory in Grodno as a collective (NHAB, f. 23, inv. 1, d. 145, p. 168). The enterprise was managed by the Kagan brothers. The company employed an accountant, a clerk, a machinist, a foreman and 24 workers (21 of whom were women) (NHAB, f. 30, inv. 1, d. 620, p. 3). Both the management and employees of the enterprise were Jewish.

In 1903-1908 in the Grodno province there were 7 tobacco factories, the productivity of which steadily increased. The production rose from 97 poods of tobacco in 1904 to 157 poods (NHAB, f. 23, inv. 1, d. 145, pp. 99-100). The industry underwent significant technical growth. The number of primitive machines was on the wane, amounting to mere $16.7 \%$ of all machines in tobacco-makhorka production in the entire province in 1908. Due to the growth of labour productivity over the decade from 1898 to 1907 , the amount of tax paid to the state treasury increased by 547 roubles, despite the decrease in the number of factories (see Table 2). The tobacco industry primarily satisfied the demand of the poorer smokers of the Grodno province. In 1898 , makhorka accounted for $86 \%$ of all tobacco products produced in the province, amounting to $88 \%$ in 1907 (NHAB, f. 23, inv. 1, d. 145, p. 168).

However, not all tobacco manufacturers operated legally. The spread of illegal production of tobacco products, associated with an increase in the excise duty, was characteristic of the 1870s. Small artisanal factories were located in the residential sector. Owners who rented out one of the rooms of an apartment were at work for the whole day did not realise immediately for what purpose the room was used. That was the case of a Brest Jew named Cheskes, who once discovered that the tenant living in 
Pobrane z czasopisma Studia Bia?orutenistyczne http://bialorutenistyka.umcs.pl

Data: 26/04/2023 17:12:07

64

Volga Sabaleuskaya

Table 2. The Amount of Processed Tobacco in the Factories of Grodno Province in 1898-1907.

\begin{tabular}{|c|c|c|c|c|c|c|}
\hline \multirow{2}{*}{ Year } & \multirow{2}{*}{$\begin{array}{c}\text { Number of } \\
\text { factories }\end{array}$} & \multicolumn{3}{|c|}{ Processed tobacco in poods } & \multicolumn{2}{c|}{ The amount of excise tax } \\
\cline { 3 - 7 } & 8 & 28110 & 186434 & 214544 & 1178573 & 29 \\
\hline 1898 & 8 & 26593 & 194882 & 221475 & 1191464 & 63 \\
\hline 1899 & 7 & 26133 & 206935 & 233068 & 1300941 & 25 \\
\hline 1900 & 8 & 24102 & 200736 & 224838 & 1314174 & 34 \\
\hline 1901 & 8 & 27436 & 203680 & 231116 & 1440801 & 60 \\
\hline 1902 & 9 & 29724 & 233599 & 263323 & 1623946 & 67 \\
\hline 1903 & 9 & 25847 & 239290 & 265137 & 1550676 & 16 \\
\hline 1904 & 9 & 23889 & 235468 & 259357 & 1507190 & 52 \\
\hline 1905 & 9 & 28347 & 255299 & 283646 & 1707333 & 51 \\
\hline 1906 & 8 & 30071 & 240553 & 270624 & 1725642 & 56 \\
\hline 1907 & 7 & & & & \\
\hline
\end{tabular}

NHAB, f. 23, inv. 1, d. 145, p. 169.

her room named Kagan produced cigars in fact. Kagan declared that his landlady had nothing to fear - should he be caught, he would have to pay a fine, after which the production would continue (NHAB, f. 581, inv. 1, d. 1179, p. 3). Hava-Sora Erlach, the owner of another Brest apartment where an underground workshop was found, stated at the investigation that she had not been aware of the illegal nature of the business, although she had been aware of the production itself (NHAB, f. 581, inv. 1, d. 1182, p. 2). Secret workshops usually employed from two to five people. For instance, Meir Levin in Brest had 6 workers, including two masters and two apprentices. He hired his indigent relative and two boys. The production was located in one room of a private apartment, while the completed products were transported secretly at night. The investigation found several poods of leaf tobacco (local, Russian and American), about 6,500 cigars, and tools for the production of cigars (table-machine, mould-press, vise) (NHAB, f. 581, inv. 1, d. 1182, pp. 3, 5, 31).

When exposed, the owner would attempt to evade all allegations and attribute blame someone else for running the illegal workshop. In fact, besides the confiscation of goods, raw materials and tools, an illegal entrepreneur was fined three times the cost of a certificate required for the opening of a factory. Furthermore, he would not be able to open a legal plant for a year. Thus, fearing a fine of 450 roubles, Meer Leibovich from Brest tried to persuade his brother-in-law to confess as the business owner. Witnesses testified:

Levin offered Amsterdamsky 100 roubles for taking all the blame if he had to pay a fine, for which Amsterdamsky would be imprisoned for 3 months for insolvency and inability to pay the fine. His wife could really use those 100 roubles, because Amsterdamsky is a poor man (NHAB, f. 581, inv. 1, d. 1182, pp. 5-6).

When Amsterdamsky did not agree, Levin tried to blame him nevertheless. 
The owner of another Brest tobacco workshop, Halabash Kagan, who was absent during the search, categorically denied any involvement in the illegal business and was only exposed by the testimony of witnesses. Not only the owner of an illegal business but also his employees were prosecuted, as they knew about the lack of a patent yet did not report it to the police and participated in the production (NHAB, f. 581, inv. 1, d. 1179, p. 3).

When a family was caught for 'clandestine tobacco manufacture,' each member would argue that they made cigars for themselves. Such was the case of a Jewish Brest resident named Meer Kolyaditsky, who claimed to have prepared some cigars for his own use during his oncoming journey. His wife and daughter were allegedly helping him in this, whereas his sister had sent the tobacco from Derechin. However, the search revealed they were using special tools (five wooden moulds, an iron vise, two knives and a box of glue) and possessed a large number of raw materials ( 6.5 pounds of sliced and 31.5 pounds of uncut tobacco leaves), as well as 200 ready-made cigars. Therefore, the court's decision favoured the prosecutor's arguments. Kolyaditsky's products and tools were confiscated and he was obliged to pay a fine of 200 roubles. (NHAB, f. 581, inv. 2, d. 1026, pp. 2, 10).

A similar event took place in Brest in 1877, when the Levin family tried to convince the court that they used the illegal workshop for producing tobacco for their own use. The landlady claimed that she had bought two poods of soaked tobacco and cigars for her husband. Having discovered special tools, 800 cigars, two poods of uncut and 2.5 poods of sliced tobacco both in the apartment and hidden in the attic, the excise officials brought the Levins to justice for running a secret tobacco factory (NHAB, f. 581, inv. 2, d. 1027, pp. 4, 11).

In several court cases, it was discovered that the organisers of secret tobacco production were Jewish women. For example, a resident of Brest called Dvosha Rosenzweig, who had tried to take a bag of packed tobacco without excise parcels out of the house, was sentenced to pay 450 roubles of a fine on the basis of paragraph 26 of article 718 of the Excise Statute, and in the case of insolvency, she would be imprisoned for two months. Police and excise officers found a man named Elkum Tenenbaum in her apartment cutting tobacco on a manual tobacco grinding machine. They found about 11 poods of tobacco prepared for cutting in the house, along with missing documents. Elkum Tenenbaum and Dvosha's husband, Elya, were acquitted. The husband claimed that he was at school all the time and was not aware of what was happening in his apartment, Tenenbaum said that he was checking a grinding machine at the request of his neighbour, who had bought the appliance earlier that day (NHAB, f. 581, inv. 2, d. 1028 , p. 2, 4).

Many illegal factories were exposed as a result of the excise officials' observation and hunt for suspects. The underground factory of Levin was found by a supervisor named V. Antsuta. He noticed a Jewish boy carrying a sack with leaf tobacco on his shoulders, followed him, and reached the house where the business was situated. Upon speaking with a local Jew, he was convinced that an underground factory was operat- 
ing in that house (New Grodno, f. 581, inv. 1, d. 1182, p. 6). Sometimes, secret cigar workshops would be reported by an anonymous informant, 'a person who does not wish to reveal his name and surname publicly' (NHAB, f. 581, inv. 1, d. 1179, p. 9).

In 1873, a case of counterfeit goods manufacture was recorded in Brest. The manufacturer G. Shapira was charged with the production of tobacco products using the labels of the famous Moscow tobacco brand Bostanjoglo and the image of a two-headed eagle, similar to the state symbols (NHAB, f. 1, inv. 23, d. 488, p). Tobacco factories which used noisy machines were undesirable for their neighbours. This is evidenced by the petition filed by Tsina Lipmanova in 1869, where she pointed at the 'harmfulness' of the tobacco factories of Gordon, Shereshevsky, Kossovsky and Russota.

The mill used for the production of snuff tobacco in the factory harms the neighbouring residents. They inhale the dust and suffer from suffocating cough and sore throat as a result (NHAB, f. 2, inv. 38, d. 703, p. 553).

The provincial government issued an order to eliminate unsafe emissions.

The residents of Tatarskaya street in Grodno, who learned about the planned relocation of B. D. Finkelstein's factory from Zamkovaya street to the immediate proximity of their houses, tried to protest

in the interest of protecting public peace and tranquillity as well as safety from fires. The opening of a factory is unthinkable in a part of the city which is densely populated, crowded, and mostly built-up with wooden buildings. Such production would disturb the residents of the city with the noise from the crowds and mills (NHAB, f. 8, inv. 2, d. 1057, p. 2).

It should be noted, however, that the Zamkovaya street, where the enterprise had been originally located, was even more overcrowded, dense and filled with wooden buildings. Having found no obstacles to the relocation of the factory, the city council moved it to a new place and banned the manufacturer from using noisy steam engines.

Tobacco production was indeed frequently accompanied by fires. The factory of I. L. Shereshevsky burned twice, in 1894 and 1901. Strict fire safety measures did not help:

A Commission consisting of three employees under the supervision of the master of each department carefully examines the factory floor on a daily basis. The Commission extinguishes the lamps, examines the furnace and the whole room very carefully, and only after that does the master lock the door of his department, and the controller seals [...] (NHAB, f. 30, inv. 1, d. 249, p. 36).

As a result of the fire from 30 January 1901, 300 workers were left unemployed, which was particularly sad in view of the approaching holiday of Purim, traditionally celebrated with magnificent feasts. It was necessary to temporarily transfer the ciga- 
rette department, where 250 people worked, to Mariinsky lane (NHAB, f. 30, inv. 1, d. 249, p. 8 ).

In the $19^{\text {th }}$ and early $20^{\text {th }}$ centuries, tobacco production was classified as harmful because of the abundance of fine dust, which had a severe impact on the workers' vision and respiratory organs. The management of large factories such as I. L. Shereshevsky's Joint Stock Company of Tobacco Factory in Grodno, having sufficient resources for the modernisation of production, aspired to buy appropriate equipment to minimise harmful emissions. In 1895, they installed a ventilation device to prevent the spread of dust from grindstones (NHAB, f. 8, inv. 2, d. 1115, p. 1).

Technological progress improved working conditions on the one hand but led to a reduction in the number of jobs on the other hand. Sanitary and hygienic conditions at I. L. Shereshevsky's tobacco factory in Grodno differed from their competitors. The plant had electric lighting and ventilation as well as steam heating, but 300 workers were dismissed upon the replacement of manual labour machine in 1908 (NHAB, f. 23 , inv. 1, d. 145, p. 168).

Tobacco factories worked 12 hours a day, the beginning and end of the work shift aligned with the length of the day. At the makhorka factory of Hinkie Muginstein and Gdalia Gechtkopf in Brest, workday started at 9 a.m. and finished at 9 p.m. from January to April and from September to December, whereas from April to September employees worked from 8 a.m. to 8 p.m. (NHAB, f. 24, inv. 4, d. 4, p. 23). At the tobacco factory of I. L. Shereshevsky in Grodno, the working day started at 7.30 a.m. and finished at 9 p.m. all year round. At the tobacco 'Manual Labour' factory, the work was performed daily from 8.30 a.m. to 8 p.m. with a lunch break from 2.30 to 4 p.m. At the 'Neman' tobacco-makhorka factory, work began at $5 \mathrm{a}$ a.m. and finished at 7.30 p.m. (NHAB, f. 30, inv. 1, d. 620, p. 1, 3).

The schedule of days off and public holidays reflects the specifics of the confession. In the Shereshevsky and 'Manual Labour' factories, where the bulk of the workers were Jews, Saturdays were the days off. These enterprises did not work on January 1, either (NHAB, f. 30, inv. 1, d. 620, p. 1, 3). As noted in the schedule of the 'Neman' factory, on the eve of Shabbat and Jewish holidays, it operated without a lunch break, but closed at 4.30 p.m. in winter and at 5.00 p.m. from April 1 to September 1. State holidays were considered to be days off: New Year (January 1), Orthodox Easter and Christmas, as well as the Jewish Judgment day (NHAB, f. 30, inv. 1, d. 500, p. 40).

Jewish religious ethics considers charity to be an indisputable duty of every Jew. Therefore, the families of wealthy tobacco manufacturers gave significant amounts of money away to charitable causes. It may be noticed that they tried to satisfy not only the material but also the spiritual needs of their workers, such as education. In the 1890 s, there was a school for Jewish children at the factory of I. L. Shereshevsky. Funds for its maintenance were also collected by the Jewish community from candle collection (NHAB, f. 2, inv. 38, d. 915, p. 157).

In the mid-1880s, when many workers in Bialystok were unemployed due to the economic crisis, the Jewish bourgeoisie made several generous donations. As a result, 
the Charity Committee was able to allocate 400 roubles for the financial assistance of families who had lost their jobs and to organise a sale of basic products at reduced prices (NHAB, f. 1, inv. 8, d. 1155, pp. 18, 23, 25).

At the beginning of the First World War, when the whole country was in a patriotic mood, the management of I. L. Shereshevsky's Joint Stock Company of Tobacco Factory in Grodno decided to donate its products for the needs of the front and the wounded. A total of 2,272,000 cigarettes and 1,000 pounds of makhorka were shipped free of charge between 4 August and 8 December 1914 (NHAB, f. 30, inv. 1, d. 962, p. 4 ; f. 983 , inv. 1 , d. 1 , pp. 3, 9, 16, 34, 36, 41).

Several tobacco manufacturers pledged to donate considerable sums for philanthropic purposes in their wills. For example, Shapir Fayvelevich Russota ordered his wife to make 'a donation to the Jewish charitable institutions of Grodno, as well as to donate at least 10,000 francs for the opening and further existence of the Jewish University in Palestine or other higher Jewish educational institution opened there' after his death (NHAB, f. 955, inv. 1, d. 3, p. 20). David Ioselevich Shereshevsky, having allocated sufficient money for his wife to sustain herself for the rest of her life, bequeathed the remaining capital to the Jewish charitable organisations in Grodno (GAGO, f. 56, inv. 1, d. 3, p. 37).

The analysis of the preserved archival documents allows for a conclusion that Jews dominated the field of tobacco production. During the second half of the $19^{\text {th }}$ and early $20^{\text {th }}$ centuries, there was noticeable progress in the manufacture of tobacco. Scientific achievements penetrated the world of production and new technologies were introduced, such as steam and electric motors or electric lighting. Large plants modernised their production process.

The greatest stability was demonstrated by large enterprises such as I. L. Shereshevsky's tobacco factory in Grodno, which had a technological and organisational advantage over its competitors. The tobacco products of the Grodno province were competitive in terms of price and quality, and they were marketed using commercial advertising techniques. They held strong positions in the market not only in the Grodno province but also in the Kingdom of Poland.

The development of the bourgeois class corresponded with the growth of production. Wealthy Jewish factory owners became respectable citizens. Money, the reputation of experienced businessmen, and charitable activities allowed them to join the multi-confessional circle of wealthy citizens of non-aristocratic origin, which broke the isolation of the traditional Jewish society. 


\section{List of sources}

NHAB - National Historical Archive of Belarus in Grodno, f. 1, inv. 8, d. 1155, d. 1159, 1262, 1263, 1264, 1266, 2361, 2429; f. 1, inv. 9, d. 1429; f. 1, inv. 22, d. 1089, 1267, 1861; f. 1, inv. 23, d. 488; f. 2, inv. 38, d. 703, 915; f. 8, inv. 2, d. 596, 1057, 1115; f. 23, inv. 1, d. 145; f. 24 , inv. 4 , d. 4 ; f. 26 , inv. 1, d. 283; f. 30 , inv. 1, d. 249 ; f. 30 , inv. 1 , d. $475,500,620$, 962; f. 581, inv. 1, d. 1179 , 1182; f. 581, inv. 2, d. 1026, 1028; f. 955, inv. 1, d. 3; f. 983 , inv. $1, \mathrm{~d} .1$.

State Archive of the Grodno Region, f. 56, inv. 1, d. 3.

Perečen' fabrik i zavodov. (1897). Sankt-Petersburg. [Перечень фабрик и заводов. (1897). Санкт-Петербург].

Polnoe sobranie zakonov Rossijskoj imperii. Collection 2. Vol. 36, sec. 2. (1863, No. 37196). Sankt-Peterburg: Gosudarstvennaâ tipografiâ. [Полное собрание законов Российской империи. Собр. 2. Vol. 36, sec. 2. (1863, №37196). Санкт-Петербург: Государственная типография].

Polnoe sobranie zakonov Rossijskoj imperii. Sobr. 2. Vol. 46, otd. 1. (1874, No. 49702). Sankt-Peterburg: Gosudarstvennaâ tipografiâ. [Полное собрание законов Российской империи. Собр. 2. Т. 46, отд. 1. (1874, №49702). Санкт-Петербург: Государственная типография].

Polnoe sobranie zakonov Rossijskoj imperii. Sobr. 3. Vol. 2, otd. 1, addition (1886, No. 895). Sankt-Peterburg: Gosudarstvennaâ tipografiâ. [Полное собрание законов Российской империи. Собр. 3. Т. 2, отд. 1, дополнение (1886, №895). Санкт-Петербург: Государственная типография].

\section{References}

Abezgauz, Zalman. (1971). Razvitie kapitalizma v Belorussii vo vtoroj polovine XIX st. Minsk: Nauka i tehnika. [Абезгауз, Залман. (1971). Развитие капитализма в Белоруссии во второй половине XIX cm. Минск: Наука и техника].

Akciz. (1893). In: F.A. Brokgauz, I.A. Efron (eds). Ènciklopedičeskij slovar' (pp. 326-331). Vol. 1. Sankt-Peterburg. [Акциз. (1893). В: Ф. А. Брокгауз, И. А. Ефрон (ред.). Энииклопедический словарь (с. 326-331). Т. 1. Санкт-Петербург].

Bašmakoǔ, A.A. (2008). Razvìccë manufakturnaga ì fabryčna-zavadskoga typaǔ pramyslovascì. Trud, prafsaûzy, gramadstva, 4, pp. 34-43. [Башмакоў, А.А. (2008). Развіццё мануфактурнага і фабрычна-завадскога тыпаў прамысловасці. Tруд, прафсаюзы, грамадства, 4, с. 34-43].

Bolbas, Maksim. (1977). Promyšlennost' Belorussii 1860-1900 g. Minsk: BGU. [Болбас, Максим. (1977). Промышленность Белоруссии 1860-1900 г. Минск: БГУ].

Golubovič, Valerij (ed.). (2001). Èkonomičeskaâ istoriâ Belarusi. Minsk: Èkoperspektiva. [Голубович, Валерий (ред.). (2001). Экономическая история Беларуси. Минск: Экоперспектива]. 
Hobsbaum, Ėrik. (1990). Vek kapitala. 1848-1875. Rostov-na-Donu: Feniks. [Хобсбаум, Эрик (1990). Век капитала. 1848-1875. Ростов-на-Дону: Феникс].

Kištymaǔ, Andrèj. (2002). Ėkanamičnyâ dasâgnennì Belarusì ǔ drugoj palove XIX-pačatku XX st. In: N. Stružynskaâ (ed.). Gistoriâ Belarusì ǔ eǔrapejskìm kantèksce (pp. 25-37). Mìnsk: Mìnskì mižnarodny adukacyjny centr. [Кіштымаў, Андрэй. (2002). Эканамічныя дасягненні Беларусі ў другой палове XIX-пачатку XX ст. У: Н. Стружынская (ред.). Гісторія Беларусі у еўрапейскім кантэксие (с. 25-37). Мінск: Мінскі міжнародны адукацыйны цэнтр].

$S$ dymkom "Pravdy': kak grodnenskie kupcy dali "prikurit" karaimskim millioneram i anglijskomu trestu. (2018). In: Ot fabriki mahorki v Lide do tabačnoj industrii Belarusi. Specproekt TUT.BY and Universal Press. Taken from: https://news.tut.by/economics/594242.html (accessed: 30 May 2018). [С дымком 'Правдыl': как гродненские купиы дали "прикурить' караимским миллионерам и английскому тресту. (2018). В: От фабрики махорки в Лиде до табачной индустрии Беларуси. Спеипроект TUT.BY и Universal Press. Режим доступа: https://news.tut.by/economics/594242.html (дата доступа: 30.05.2018)].

Saladkov, Iosif. (1957). Social'no-èkonomičeskoe položenie Belorussii do Oktâbr'skoj socialističeskoj revolûcii. Minsk: Politliteratura. [Саладков, Иосиф. (1957). Соииальноэкономическое положение Белоруссии до Октябрьской сочиалистической революиии. Минск: Политлитература].

Šybeka, Zahar. (1997). Garady Belarusì. Mìnsk: Belarus'. [Шыбека, Захар. (1997). Гарады Беларусі. Мінск: Беларусь]. 